\title{
Discussing the Impact of COVID-19 on Mental Health from a Psychological Perspective
}

\author{
Masayo Uji \\ Department of Nursing, Yasuda Women's University, Hiroshima, Japan \\ Email: ujimasayo@hotmail.co.jp
}

How to cite this paper: Uji, M. (2020). Discussing the Impact of COVID-19 on Mental Health from a Psychological Perspective. Psychology, 11, 1005-1008. https://doi.org/10.4236/psych.2020.117065

Received: June 17, 2020

Accepted: July 14, 2020

Published: July 17, 2020

Copyright $\odot 2020$ by author(s) and Scientific Research Publishing Inc. This work is licensed under the Creative Commons Attribution International License (CC BY 4.0).

http://creativecommons.org/licenses/by/4.0/

\begin{abstract}
Under the socially critical situations, an individual's personality pathologies tracing back to their origins a long time ago are usually exacerbated, and hidden group mentality of society as a whole is manifested. The COVID-19 outbreak, which has brought about an extremely high level of crisis all over the world, provides us with an opportunity to observe pathologies of society in addition to those of an individual more vividly, helping us understand the meanings of the pathologies. In this study, attitudes and behavioral reactions of Japanese individuals and society as a whole caused by the COVID-19 outbreak were discussed. Psychoanalytic and social psychology theories as well as self-determination theory were applied for discussing some behavioral phenomena, such as addiction behaviors and crude criticism and/or discrimination towards some particular category of people. After proposing some hypotheses regarding these attitudes and behaviors, I finally mentioned tasks with which COVID-19 challenges human society. I refer to the increased need for clinical psychiatry and psychology in contributing to society to achieve the tasks.
\end{abstract}

\section{Keywords}

COVID-19, Mental Health, Group Mentality, Addiction, Autonomy

\section{Introduction}

In addition to the power of the virus, the restriction of freedom and adaptation to a new lifestyle has become cause of people's stress, anxiety, and fear, which manifest a variety of visible behavioral reactions among society as a whole. I would like to discuss the reaction of people in society provoked by COVID-19, both reported by media and that which I observed and experienced as a clinician as well as a faculty member of a university in Japan, using some theories of psychology. 


\section{Discussion}

From the viewpoint of public health, the infected individual was quarantined, and the source and route of transmission were examined. The number of infected people daily reported by the Ministry of Health, Labor and Welfare brings about people's anxiety or temporary relief. Each individual is required to cooperate with strict and sometimes compulsive self-control: frequent hand-washing and disinfection, avoidance of close contact with others, refrainment from travelling, etc. Nature of motivation to cooperate depends on the individual. More than half would be willing to cooperate autonomously wishing for public well-being [integrated regulation (Deci, 1996)]. On the other hand, some people would cooperate from fear of becoming a target of criticism by and elimination from society [external regulation (Deci, 1996)]. Indeed, not only people who do not adhere to public requirements, but some infected people are also criticized and discriminated, in particular, on the social networking sites. Unfortunately, medical staff and their family members are also discriminated when receiving public services. These are deviated from our original real task: defense against or, though yet impossible, elimination of the virus. The group mentality manifested by these deviated attitudes is what Bion calls the fight-flight basic assumption group [Baff] (Bion, 1961). Ruthless harassment by so called "lock-down police" attempting to close restaurants has attacked owners although they are not required by their local government to close. These actions can be regarded as not only explosions of frustration or aggression, which had been smoldering before COVID-19, but were intensified in order to sweep away anxiety caused by COVID-19. For those who united as "lock-down police" needed scapegoats which they identified as "social evils". The hypomanic message to society encouraging people to unite, and not succumb to the virus (as commonly seen during natural disasters), comes with the risk of excluding an individual who are discouraged.

One of my patients gained weight during the period of the local government's request to stay inside. COVID-19 enhanced his feeling of loneliness, which plunged him to oral stage (Freud, 1905). Overeating, however, was one of the commonly seen behavioral reactions under the COVID-19 outbreak. It is probable that other behaviors of addiction, such as abuse of alcohol, caffeine, and nicotine also have been triggered or worsened among those with high needs for interpersonal dependency.

Maladaptive usage of internet and mobile phone text-message services also has been a psychological and psychiatric focus for its addiction-related behaviors (Li, Hou, Yang, Jian, \& Wang, 2019; Hong, Liu, Ding, Sheng, \& Zhen, 2020; Chun, Har, Yan, Kuen, Yan, Man et al., 2020). On the other hand, internet and mobile phones enabled remote classes and provided social support, etc. My university students had to attend online classes individually at home. Their opportunities to see classmates were taken away. Some students, those with high ego function (Bellack, Hurvich, \& Gediman, 1973), were able to keep working on 
their own real task even under this critical situation, and utilize mutual support using email and/or mobile phone when necessary. They are autonomous and undaunted to the anxiety of aloneness.

Other objects for addiction such as alcohol or exercise (Christo, Jones, Haylett, Stephenson, Lefever, \& Lefever, 2003) also are not problematic themselves. It depends on the individual whether the above objects are utilized adequately or not. In particular, while society requires social-distancing, the internet and mobile phones are part of our lives. Therefore, it is expected that future epidemiological research targeting not only general population but also patient population, will clarify the characteristics of individuals who fall into addiction behaviors. Psychotherapies and/or social therapies for those with addiction behaviors also remain to be established.

In order for people to be mentally healthy, it goes without saying that the social system has to allow them to exercise their autonomy. Under socially critical situations where the social system restricts people's autonomy, the need for clinical psychiatry to provide psychological interventions will increase for people who present various prototypes of maladaptive behavioral manifestations including addiction behaviors, which probably had their origin far before the COVID-19.

\section{Conclusion}

Behavioral reactions observed among Japanese people as well as those of society as a whole are regarded as manifestations of pathologies which had existed before the COVID-19 outbreak. COVID-19 merely revealed those pathologies. The pathway from aloneness brought about by the COVID-19 outbreak to addiction behaviors seems to be intermediated by individual personality pathologies. Even under this critical situation, autonomous individuals are not susceptible to the pathologies of other people and society, and are able to keep working on their real task. However, COVID-19 is still a threatening challenge for human society. COVID-19 appeared to test ego functions of not only individuals but also those of society as a whole, i.e. adaptability, flexibility, integration, autonomy, and cooperativeness, etc. Expectations are anticipated for society to increase its maturity through the COVID-19 outbreak. For individuals who are trapped in self-destructive addiction behaviors due to his/her inability to bear with the anxiety of aloneness, psycho-social intervention is necessary. Clinical psychiatry and psychology should deliberate on how to contribute to completing this task.

\section{Conflicts of Interest}

The author declares no conflicts of interest regarding the publication of this paper.

\section{References}

Bellack, L., Hurvich, M., \& Gediman, H. (1973). Ego Functions in Schizophrenics, Neu- 
rotics, and Normals. New York: Wiley.

Bion, W. (1961). Experiences in Groups and Other Papers. London and New York: Routledge.

Christo, G., Jones, S. L., Haylett, S., Stephenson, G. M., Lefever, R. M. H., \& Lefever, R. (2003). The Shorter PROMIS Questionnaire Further Validation of Tool for Simultaneous Assessment of Multiple Addictive Behaviours. Addictive Behaviors, 28, 225-248. https://doi.org/10.1016/S0306-4603(01)00231-3

Chun, K. N., Har, L. W., Yan, H. L., Kuen, L. L., Yan, P. N., Man, C. N. et al. (2020). The Relationships between Mobile Phone Use and Depressive Symptoms, Bodily Pain, and Daytime Sleepiness in Hong Kong Secondary School Students. Addictive Behaviors, 101, Article ID: 105975. https://doi.org/10.1016/j.addbeh.2019.04.033

Deci, E. L. (1996). Why We Do What We Do: Understanding Self-Motivation. New York: Penguin Books.

Freud, S. (1905). Three Essays on the Theory of Sexuality. In J. Strachy, \& A. Freud (Eds.), The Standard Edition of the Complete Psychological Works of Sigmund Freud, Volume VII (1901-1905): A Case of Hysteria, Three Essays on Sexuality and Other Works (pp. 123-246). London: Hogarth Press.

Hong, W., Liu, R-D., Ding, Y., Sheng, X., \& Zhen, R. (2020). Mobile Phone Addiction and Cognitive Failures in Daily Life: The Mediating Roles of Sleep Duration and Quality and the Moderating Role of Trait Self-Regulation. Addictive Behaviors, 107, Article ID: 206383. https://doi.org/10.1016/j.addbeh.2020.106383

Li, G., Hou, G., Yang, D., Jian, H., \& Wang, W. (2019). Relationship between Anxiety, Depression, Sex, Obesity, and Internet Addiction in Chinese Adolescents: A Short-Term Longitudinal Study. Addictive Behaviors, 90, 421-427.

https://doi.org/10.1016/j.addbeh.2018.12.009 